\title{
Study of Arboviruses in Philander opossum, Didelphis marsupialis and Nectomys rattus captured from forest fragments in the municipality of Belém, Pará, Brazil
}

\author{
Marcella Katheryne Marques Bernal ${ }^{1 *}$ (i) Jannifer Oliveira Chiang ${ }^{2}$ \\ Fernanda Figueiredo Mendes ${ }^{1}$ (i) Sara Letícia dos Santos Andrade ${ }^{1}$ \\ Sandy Kelly Souza Marques da Silva ${ }^{3}$ Washington Luiz Assunção Pereira ${ }^{1}$
}

\begin{abstract}
${ }^{1}$ Laboratório de Patologia Animal, Universidade Federal Rural da Amazônia (UFRA), 66077-530, Belém, PA, Brasil. E-mail: mkbernalfh@gmail.com. ${ }^{*}$ Corresponding author.

${ }^{2}$ Laboratório de Arbovirologia e Febres Hemorrágicas, Instituto Evandro Chagas (IEC), Ananindeua, PA, Brasil.

${ }^{3}$ Universidade Federal do Pará (UFPA), Castanhal, PA, Brasil.

ABSTRACT: Arboviruses are viruses that maintain their life cycle in the wild and are transmitted to vertebrate hosts by hematophagous diptera. They are zoonotic and can establish an enzootic cycle in the urban areas; in humans, the infection can manifest from being encephalitogenic to hemorrhagic. This study aimed to report the occurrence of arboviruses in mammals of the order Didelphimorphia and Rodentia, captured from the Amazon. Serum samples were subjected to hemagglutination inhibition test using a viral panel of 19 species of arboviruses that are known to occur in the Amazon. Altogether, 14 wild mammals, 12 of Philander opossum, 1 of Didelphis marsupialis, and 1 of Nectomys rattus were captured. Eight of these were reported to be seropositive for arboviruses (57.14\%) with monotypic seroprevalence for the Eastern Equine Encephalitis Virus $(n=1)$, the Ilheus Virus $(n=2)$, and the Catu virus $(n=4) ; 4$ heterotypic responses were observed for Flavivirus and Orthobunyavirus. In conclusion, several arbovirus species are in active circulation and maintenance, exhibiting enzootic characteristics in the wild mammals of the Amazon region; these animals prove to be potential hosts in the transmission of diseases to humans.

Key words: arboviruses, wild mammals, Amazônia.
\end{abstract}

Estudo de Arbovírus em Philander opossum, Didelphis marsupialis e Nectomys rattus capturados em fragmentos florestais no município de Belém, Pará

RESUMO: Os arbovirus são vírus que mantêm o seu ciclo de vida em ambiente silvestre. Eles são transmitidos aos hospedeiros vertebrados por dípteros hematófagos, tem caráter zoonótico podendo estabelecer um ciclo enzoótico no meio urbano, sendo que em humanos a infecção pode ter caráter encefalomiogênico a hemorrágico. Este estudo teve como objetivo relatar a ocorrência de arbovírus em mamíferos da ordem Didelphimorphia e Rodentia capturados na Amazônia. Os soros dos animais foram submetidos a testes de Inibição da Hemaglutinação utilizando um painel viral com as 19 principais espécies de arbovírus que ocorrem na Amazônia. Foram capturados 14 espécimes de mamiferos silvestres, 12 Philander opossum, 1 Didelphis marsupialis e 1 Nectomys rattus. A soropositividade para arbovírus foi observada em $57,14 \%$ (8/14) dos espécimes estudados, com soroprevalência monotípica para o vírus da Encefalite Equina do Leste ( $n=1)$, o vírus Ilheus $(n=2)$ e o vírus Catu $(n=4)$ e quatro reações heterotípicos para Flavivírus e Orthobyavírus. Conclui-se que há manutenção e circulação de espécies de arbovírus com características enzoóticas em mamíferos silvestres da região amazônica, podendo ser hospedeiros em potenciais na transmissão da doença para humanos.

Palavras-chave: arboviroses, mamiferos silvestres, Amazônia.

\section{INTRODUCTION}

The Amazon region has a wide variety of fauna and flora, biogeographically exhibiting a heterogeneous distribution of various species such as didelphis and rodents(EMMONS, 1997), making these animals vulnerable to minor environmental changes (THIOLLAY, 1994). The orders Didelphimorphia and Rodentia represent a significant percentage of the diversity observed amongst species of small mammals in the Amazon region (EMMONS; FEER, 1997). In Brazil, there are approximately 267 species of registered, small, non-flying mammals, of which 88 are endemic to the Amazon biome (PAGLIA et al., 2012; DUTRA et al., 2013). These animals have colonized practically all the ecosystems with very 
varied eating habits (GARDNER, 2015) and provide essential services especially with respect to seed dispersal and germination (MORAND et al., 2006). However, several small mammals are considered agricultural pests, as they act as hosts and reservoirs for pathogenic species that affect humans and domestic animals (MORAND et al., 2006). This duality, is an important component of biodiversity and disease transmission; it represents a negative factor for the human well-being, leading to numerous studies on Didelphimorphia and Rodentia worldwide (WOLFF; SHERMAN, 2007).

According to GILLESPIE \& PEARSON (2001), some mammals in the Amazon partially depend on the natural environment to survive - they are considered as non-commensal, synanthropic animals; these also include some representatives of the orders Didelphimorphia and Rodentia. Such mammals can be potential vectors of zoonotic arbovirus infections.

Arbovirus infections may occur in the wild mammals either as an endemic or an epidemic and are transmitted to a susceptible host during a blood-sucking meal by arthropods. The Amazon is; therefore, wellknown for having a great diversity in their faunaboth for invertebrates and vertebrates, in addition to the favorable climatic conditions for maintenance of arboviruses (TRAVASSOS DA ROSA et al., 1997).

In the recent few years, several emerging and re-emerging arboviruses have been reported, including some with pathogenicity for animals and humans; of the 500 arboviruses registered globally, a vast majority of the new occurrences are a result of climatic changes and vector based transmissions (MARCONDES et al., 2017). While some of these affect domestic animals and humans without a notable clinical manifestation, disease signs are evident in the wild niches where there is active circulation of arboviruses (FIGUEIREDO, 2000).

The municipality of Belém has deforested $51 \%$ of the total area; however, it is possible to verify the existence of small biological islets sharing an anthropic environment (FERREIRA et al., 2012); thus, human inhabitants of the Amazonian have a close contact with the wild fauna near residential areas. Therefore, the objective of this research was to report arbovirus prevalence in mammals of the order Didelphimorphia and Rodentia captured from a forest fragment in the university campus of Belém, at Pará State, Brazil.

\section{MATERIALS AND METHODS}

Samples

Using the Tomahawk and Sherman traps, four species of animals were captured from the secondary forest fragment around the campus of the Federal Rural University of the Amazon (UFRA), (latitude $1^{\circ} 28^{\prime} \mathrm{S}$, longitude $48^{\circ} 29^{\prime} \mathrm{W}$ ), located in Belém. They were identified with the help of taxonomic keys specific to the respective orders, the coloring patterns of the coat, and their morphometric parameters. The animals were captured using the 70 Tomahawk and Sherman traps following the methodology of Auricchio and Salomão (2002). Briefly, the animals were identified individually and the traps were disinfected after each capture; the traps were distributed and placed in the understory areas and woodlands, separated by a distance of 20 meters. A mixture of peanut butter, sardines, oil, bananas and corn was used as bait. The surveys were carried out between 7 to 8 a.m. in the morning, since majority of the species have twilight and nocturnal habits (EMMONS; FEER, 1997).

\section{Collection of serum sample}

To collect blood, the captured animals were physically restrained with leather shavings, subsequently weighed and intramuscularly administered ketamine $(0.2 \mathrm{ml} / \mathrm{kg})$ and xylazine $(0.15 \mathrm{ml} / \mathrm{kg})$; blood was obtained from the lateral caudal vein with volume equivalent to approximately $10 \%$ of the animal weight (CUBAS et al., 2007). Samples were stored in collection flasks without an anticoagulant, centrifuged at 3,200 rpm to obtain the serum sample and stored at $-20{ }^{\circ} \mathrm{C}$ until further use.

\section{Hemagglutination inhibition test}

Serum samples were tested at the Arbovirology and Hemorrhagic Fevers Laboratory of Evandro Chagas Institute (Ananindeua city, state of Pará, Brazil) using the hemagglutination inhibition test (HI), according to the technique described by CLARKE \& CASSALS (1958) and adapted for microplates by SHOPE (1963). A panel of 19 arbovirus antigens belonging to the following families was used: Togaviridae [Madariaga virus (MADV), Western Equine Encephalitis virus (WEEV), Mayaro virus (MAYV) and Mucambo virus (MUCV)]; Flaviviridae [Yellow Fever virus (YFV), Ilhéus virus (ILHV), Saint Louis Encephalitis virus (SLEV), Cacipacore virus (CPCV), Bussuquara virus (BUSV) and Rocio virus (ROCV)] and Bunyaviridae [Guaroa virus (GUAV), Tacaiuma virus (TACV), Maguari virus (MAGV), Utinga virus (UTIV), Caraparu virus (CARV), Oropouche virus (OROV), Catu virus (CATV), Belém virus and Icoaraci virus (ICOV)]. The serum samples were pretreated with acetone to concentrate proteins and remove natural inhibitors as 
well as adsorbed with red blood cells to remove nonspecific hemagglutinins. Positive samples were analyzed based on the titrations ranging from 1:40 to 1:1280. HI was chosen as it is the standard methodology used for serological screening of arboviruses.

\section{Statistical analysis}

The data obtained was tabulated and analyzed using simple descriptive statistics.

\section{RESULTS AND DISCUSSION}

Thus, altogether 14 fourteen animal species were captured: 12 of Philander opossum, 1 Didelphis marsupialis and 1 Nectomys rattus; 8 (57.14\%) of which were seropositive for one or more arboviruses. Monotypic reactions were observed (Table 1) for MADV $(n=1)$, ILHV $(n=2)$ and CATV $(n=4)$; the titration between arbovirus genera of monotypic reactions ranged from 1:20 to 1:160 (Table 2). In total, 4 heterotypic reactions were observed for viruses of the genus Flavivirus and Orthobunyavirus. These results indicated cross-reactivity; the animals may have been exposed to two genera of viruses in their lifetime.

Arboviruses can cause endemics or epidemics and are transmitted by vectors such as hematophagous diptera to several species of wild animals as definitive hosts and to humans as accidental hosts (LEÃO, 1997). MURRAY et al. (2002) reported that these viruses can infect all representatives of the subphylum vertebrate.

It is noteworthy that the Amazon with its wide fauna diversity makes a potential reserve for these viruses and the presence of arboviruses belonging to Flaviviridae and Bunyaviridae has already been reported in Nectomys sp. and Didelphis sp., considering they are sentinel mammals (WOODALL, 1967).
NUNES et al. (2009) carried out a study on marsupials and rodents in the Pará State; the following were seronegative for arboviruses Metachirus nudicaudatus, Philander opossum, Didelphis albiventris, Caluromys philander, Proechymis guyanensis, Oryzomys goeldi and Nectomys squamata. In a similar study by CRUZ et al. (2009) D. marsupialis, D. albiventris, Proechimys guianensis and Proechimys longicaudatus from Juriti municipality were also negative for arboviruses.

However in the present study, $P$. opossum, D. marsupialis and Nectomys rattus were reported to be seropositive for arboviruses. This may be related to the presence or absence of ecological niches favoring active circulation of arboviruses in didelphis located in different parts of the state (DÉGALLIER et al., 1986; TORTORA et al., 2005).

In the present study, a monotypic reaction for MADV was observed in D. marsupialis an unprecedented occurrence for the species; in addition, it increased the possibility of infection in other species of mammals. Dégallieret et al. (1986) stated that the wild cycle of this arbovirus may involve species of rodents, didelphis, birds and mosquitoes. Culicidae is a common vector for MADV (TORTORA et al., 2005) and the horse may be an example of a susceptible host with a mortality rate of approximately $35 \%$ a clinical resolution or sequelae of brain damage and deafness (MURRAY et al., 2002). In Panama, CARRERA et al. (2013) used phylogenetic analysis to identify an enzootic lineage present in horses infected with this virus, in addition to that reported in humans.

ILHV arbovirus causes fever, headache, arthralgia, myalgia, photophobia, and asthenia in humans and is of great interest to public health (PINHEIRO et al., 1986). This encephalitogenic flavivirus has been studied in the South American countries (TRAVASSOS DA ROSA et al. 1998);

Table 1 - Hemagglutination inhibition test results for the presence of arboviruses in animals of the orders Didelphimorphia and Rodentia from the forest fragments on the campus of Federal Rural University of the Amazon, in Belém, Pará.

\begin{tabular}{|c|c|c|c|c|c|}
\hline \multirow[t]{2}{*}{ Species } & \multicolumn{3}{|c|}{-------------------'Monotypic reactions------------------- } & \multicolumn{2}{|c|}{---------------Heterotypic reactions-------------- } \\
\hline & VEEE & VCAT & VILH & Flavivírus & Orthobunyavírus \\
\hline Didelphis marsupialis & $1(7,1 \%)$ & $0(0 \%)$ & $0(0 \%)$ & $1(7,1 \%)$ & $1(7,1 \%)$ \\
\hline Philander opossum & $0(0 \%)$ & $3(21,1 \%)$ & $2(14,3 \%)$ & $2(14,3)$ & $0(0 \%)$ \\
\hline Nectomys rattus & $0(0 \%)$ & $1(7,1 \%)$ & $0(0 \%)$ & $0(0 \%)$ & $0(0 \%)$ \\
\hline Total & 1 & 4 & 2 & 3 & 1 \\
\hline
\end{tabular}

*VEEE: Eastern Equine Encephalitis virus, VCAT: Catu virus, VILH: Ilheus vírus. 
Table 2 - Frequency distribution of arbovirus hemagglutination inhibitors for D. marsupialis, P. opossum and $N$. rattus captured on Federal Rural University of the Amazon campus, Belém, PA.

\begin{tabular}{lccc}
\hline Arbovírus & & & \\
& & & \\
& & & \\
VEEE & $1: 20$ & $1: 40$ & $1: 80$ \\
VCAT & 1 & - & - \\
VILH & 2 & 1 & - \\
\hline
\end{tabular}

*VEEE: Eastern Equine Encephalitis virus, VCAT: Catu virus, VILH: Ilheus vírus.

one of the first records was of animals in Brazil non-human primates characterized as sentinel animals due to manifestation of pathognomonic clinical signs, bats were also included as important reservoirs for the spread of the disease (PINHEIRO, 1982). Travassos da Rosa et al. (1992) reported that avifauna in the Amazon region does not show any clinical signs but are propagators of the virus due to their migratory behavior.

RIBEIRO et al. (2006) detected ILHV in the sera of asymptomatic Bubalus bubalis marketed in the region under the municipality of Soure, Marajó, Pará. Animals that have the capacity to be asymptomatic reservoirs of zoonotic viruses and are in close proximity to man, can be fundamental in maintaining the disease cycle and instrumental for epidemiological studies. In the present research, $2 P$. opossum were asymptomatic but positive for ILHV and MADV; to the best of our knowledge this is the first report of these flaviviruses in a rodent species with synanthropic habits. This suggested an active circulation of the virus in the islets and biological areas surrounding the university space, making it imperative to alert the community of a possible maintenance of an enzootic cycle.

The Bunyaviridae family consists of 350 RNA viruses organized into five genera, including the Orthobunyavirus consisting of 18 serogroups (HORNE; VALANDINGHAM, 2014), amongst them the Guamá group has 7 viruses isolated from the Amazon, 2 of which are encephalitogenic exhibiting clinical signs in humans Catu and Guamá (LEÃO et al., 2013). The Catu virus is characterized as having a wide geographical distribution among the Amazonians; the first clinical signs are febrile symptoms with evolution of holocranial headaches (NUNES et al., 2005; LEÃO et al., 2013). In the present study, Catu virus was detected at a titre of 1:160 in a specimen of $N$. rattus; this new record contributed to the future epidemiological studies on the disease and its plausible relationship with wild hosts.

Detection of antibodies against some of the main arboviruses present in the Amazon suggests that these animals may have been infected earlier, during some stage of their lives and may now present an eco-epidemiological environment favorable for the circulation and maintenance of pathogens. Moreover, presence of susceptible hosts close to the wild niches with demonstrated positivity for these viruses, in the area encompassing the Federal Rural University of the Amazon emphasizes the need for attention from public health agencies.

\section{CONCLUSION}

Small, non-flying mammals $D$. marsupialis, $P$. opossum, and $N$. rattus present in the secondary forest fragments can maintain circulation of arboviruses such as MADV, ILHV and CATV in their niche. Pathogens from the wild biotas reported in an urban area with humans and domestic animals may pose a risk to public health, making it increasingly important to monitor the dynamics of circulating arbovirus strains, particularly since the viruses identified on university campus are encephalitogenic in nature.

\section{ACKNOWLEDGEMENTS}

I thank the laboratory support of the Animal Pathology Laboratory of the Federal Rural University of the Amazon, and the Arbovirology laboratory of the Evandro Chagas Institute. And was financed in part by the Coordenação de Aperfeiçoamento de Pessoal de Nível Superior (CAPES), Brasil.

\section{BIOETHICS AND BIOSSECURITY COMMITTEE APPROVAL}

This research was approved by the Ethics Committee on the Use of Animals (CEUA) of the Universidade Federal 
Rural da Amazônia: 032012-30 and authorized by the Brazilian Institute of Environment and Renewable Natural Resources (IBAMA): 40309-1.

\section{DECLARATION OF CONFLICT OF INTERESTS}

The authors declare no conflict of interest. The founding sponsors had no role in the design of the study; in the collection, analyses, or interpretation of data; in the writing of the manuscript, and in the decision to publish the results.

\section{AUTHORS' CONTRIBUTIONS}

All authors contributed equally for the conception and writing of the manuscript. All authors critically revised the manuscript and approved of the final version.

\section{REFERENCES}

CLARKE, D. H.; CASALS, J. Techniques for hemagglutination and hemagglutination-inhibition with arthropod-borne viruses. American journal of tropical medicine and hygiene, v.7, p.561573, 1958. Available from: <http://www.ajtmh.org/docserver/ fulltext/14761645/7/5/TM0070050561.pdf? expires $=159105318$ $0 \& \mathrm{id}=\mathrm{id} \&$ acc name $=$ guest $\&$ checksum $=71 \mathrm{CEBE} 6 \mathrm{~A} 6 \mathrm{FC} 33 \mathrm{C} 148$ A1A04F281F4D0DA>. Accessed: Dec. 06, 2019. doi: 10.4269/ ajtmh.1958.7.561.

CARRERA, J. P.; et al. Eastern Equine Encephalitis in Latin America. The New Engladn Journal of Medicina, v.369, n.8, p.2-13, 2013. Available from: <https://www.nejm.org/doi/ full/10.1056/NEJMoa1212628>. Accessed: Sep. 09.2020. doi: 10.1056/NEJMoa1212628

CRUZ, A. C. R.; et al. Serological survey for arboviruses in Juruti, Pará State, Brazil. Cadernos de Saúde Pública, v.24, p.25172523, 2009. Available from: <https://doi.org/10.1590/S0102 311X2009001100021>. Accessed: Dec. 06, 2019. doi: 10.1590/ S0102-311X

CUBAS, Z. S.; et al. Tratado de animais selvagens. São Paulo: Roca, 2007.

DÉGALLIER, N.; et al. Ecology of arboviruses in the Amazon: current research and perspective. Revista da Fundação SESP v.31, p.127-130, 1986. Available from: <http://patua.iec.gov.br/ handle/iec/341>. Accessed: Dec. 28, 2019.

EMMONS, L; FEER, F. Neotropical rainforest mammals. A field guide. Second edition. Chicago: The University of Chicago Press, 1997.

FERREIRA, L. V.; et al. O feito da fragmentação e isolamento florestal das áreas verdes da Região Metropolitana de Belém. Pesquisa Botânica, v.63, p.358-367, 2012. Available from: $<$ http:// www.anchietano.unisinos.br/publicacoes/ botanica/botanica63/14 pdf>. Accessed: Dec. 28, 2019.

FIGUEIREDO, L. T. M. The brazilian flaviviruses. Microbes and Infections, v.13, p.1643-1649, 2000. Available from: $<$ https:/www.sciencedirect.com/ science/ article/ abs/ pii/ S1286457900013204?via\%3Dihub>. Accessed: Dec. 28, 2019. doi: 10.1016/s1286-4579(00)01320-4.
GARDNER, A. In WILSON, D. E.; REEDER, D. M. (eds). Mammal Species of the World. $3^{\text {a }}$ edição, Johns Hopkins University Press, p.3-18, 2015.

GILLESPIE, S. H.; PEARSON, R. D. Principles and Practice of Clinical Parasitology. USA: Copyright Virgina, 2001.

HORNE, K. M.; VANLANDINGHAM, D. L. Bunyavirus-vector interactions. Viruses, v.6, p.4373-4397, 2014. Accessed: Sep. 07, 2020. doi: 10.3390/v6114373.

LEÃO, R. N. Q. Doenças Infecciosas e Parasitátia: Enfoque Amazônico. Cejup: Belém, Universidade do Estado do Pará, p.207-225, 1997.

LEÃO, R. N. Q.; et al. Medicina Tropical e Infectologia na Amazônia. Samauma: Belém, Instituto Evandro Chagas, vol.1, p.481-504, 2013.

MARCONDES, C. B.; et al. Emergent and Reemergent Arboviruses in South America and the Caribbean: Why So Many and Why Now? Jounal of Mededical Entomology, v.54, p.509-532, 2017. Available from: <https://pubmed.ncbi.nlm.nih.gov/28399216/>. Accessed: Sep. 07, 2020. doi: 10.1093/jme/tjw209.

MORAND, S.; et al. Micromammals and Macroparasites. Evolutionary Ecology to Management. Tokyo, Japan, Springer, 2006 .

MURRAY, P. R.; et al. Medical microbiology. 4th ed. St Louis: MOSBY, 2002.

NUNES, M. R. T.; et al. Eco-epidemiologia dos arbovírus na áera de influência da rodovia Cuiabá-Santarém (BR 163), Estado do Pará, Brasil. Rio de Janeiro. Cadernos de Saúde Pública, v.25, p.2583-2602, 2009. Available from: <https://doi.org/10.1590/ S0102-311X2009001200006>. Accessed: Dec. 28, 2019. doi: 10.1590/S0102-311X2009001200006.

NUNES, M. R. T.; et al. Molecular Epidemiology of Group C Viruses (Bunyaviridae, Orthobunyavirus) isolated in the Americas. Journal Virology, v.79, n.16, p.10561-10570, 2005. Available from: < https://jvi.asm.org/content/79/16/10561>. Accessed: Sep. 07, 2020. doi: 10.1128/JVI.79.16.10561-10570.2005.

PAGLiA, A. P.; et al. Lista Anotada dos Mamíferos do Brasil. $2^{\mathrm{a}}$ Edição. Occasional Papers in Conservation Biology, Conservation International, Arlington, VA, n.6, p.76, 2012.

PINHEIRO FP. Simpósio Internacional sobre Arbovírus dos Trópicos e Febres Hemorrágicas, Belém, 1980. Rio de Janeiro, Academia Brasileira de Ciências, 1982. 481p.

PINHEIRO, F. P.; et al. Arboviroses: Aspectos clínicoepidemiológicos. In: Instituto Evandro Chagas: 50 anos de contribuição às ciências biológicas e à medicina tropical. Belém: Fundação Serviço de Saúde Pública, v.1, p.375-408, 1986.

THIOLLAY, J. M. Structure, Density and Rrity in an Amazonia Rainforest Bird Community. Journal of Tropical Ecology, v.10, p.4449-481, 1994. Available from: <https://doi.org/10.1017/ S0266467400008154>. Accessed: Dec. 28, 2019. doi: 10.1017/ S0266467400008154.

TORTORA, G. J.; et al. Microbiologia. 8th ed. Porto Alegre: Artmed, 2005, p.627-629. 
TRAVASSOS DA ROSA, A. P. A.; et al., Arboviruses in Serra Norte, Carajás region, Pará, Brazil. Journal of the Brazilian Association for the Advancement of Science, v.44, p.158161, 1992. Available from: <https://patua.iec.gov.br/handle/ iec/2722?show=full>. Accessed: Dec. 28, 2019.

TRAVASSOS DA ROSA, A. P. A.; et al., Arboviroses. In: LEÃO, R.N.Q. Doenças infecciosas e parasitárias - enfoque amazônico. Instituto Evandro Chagas. Belém: CEJUP UEPA, 1997, p. 207-225. Available from: <https://pesquisa.bvsalud.org/portal/resource/pt/ sus-6283>. Accessed: Dec. 28, 2019.

TRAVASSOS DA ROSA, J. F. S.; et al.,. Arboviruses isolated in the Evandro Chagas Institute, including some described for the first time in the Brazilian Amazon region, their known hosts and their pathology for man. In: TRAVASSOS DA ROSA, A. P. A, VASCONCELOS, P. F. C., TRAVASSOS da ROSA, J. F. S,
(Eds). An overview of arbovirology in Brazil and neighboring countries. Instituto Evandro Chagas, Belém; p.19-31, 1998. Available from: $<$ https://patua.iec.gov.br/bitstream/handle/iec/189/ Arboviruses $>$. Accessed: Nov. 03, 2019.

SHOPE, R. E. The use of micro-hemagglutination inhibition test to follow antibody response after arthropod borne virus infection in a community of forest animals. Rio de Janeiro. Anais de Microbiologia, v.11, p.167-171, 1963. Available from: <http://iah.iec.pa.gov.br/iah/ fulltext/memo_iec/v7p175-178.pdf>.Accessed: Dec. 28, 2019.

WOLFF, J. O.; SHERMAN, P. W. Rodent Societies: An Ecological and Evolutionary Perspective. Chicago, USA. The University of Chicago Press, 2007.

WOODALL, J. P.. In: Atas do Simpósio sobre a Biota Amazônia (Patologia), v.6, p.31-63, 1967. 